\title{
Bimetallic Gold-Containing Catalysts for the Selective Oxidation of a-Pinene: The Formation of a Green Natural Monomer
}

\author{
Fouzi M Muhsen ${ }^{1}$, Hussein M Etmimi ${ }^{2 *}$ and GJ Hutchings ${ }^{3}$ \\ ${ }^{1}$ Petroleum Training and Qualifying Institute, Libya \\ ${ }^{2}$ Polymer Research Center, Libya \\ ${ }^{3}$ School of Chemistry, UK \\ *Corresponding author: Hussein M Etmimi, Libya
}

Submission: 眥July 07, 2018; Published: 眥 August 31, 2018

\begin{abstract}
Various bimetallic (i.e., $\mathrm{Au}-\mathrm{M}$, where $\mathrm{M}=\mathrm{Pd}, \mathrm{Cu}$, $\mathrm{Co}$ or $\mathrm{Fe}$ ) gold-containing catalysts were prepared and tested for the oxidation of $\alpha$-pinene. All catalysts were prepared by impregnation method on $\mathrm{TiO}_{2}$ support and compared to determine the best and most active catalyst for the selective oxidation of $\alpha$-pinene. Although, the reaction resulted in the formation of a variety of products including: pinene oxide, verbenol, verbenone, carveol, and carvone, however the emphasis was on studying the effect of increasing the catalytic mass and reaction time, particularly during the conversion of $\alpha$-pinene to pinene oxide. Other catalysts namely, $\mathrm{CoCu}, \mathrm{Cu}, \mathrm{PdCu}, \mathrm{FeCu}, \mathrm{Pd}$ and $\mathrm{Fe}$ were studied for comparison. After 24 hours, the catalytic activity of all the studied systems was observed to be in the order of: $\mathrm{CoCu}>\mathrm{Cu}>\mathrm{AuCu}>\mathrm{PdCu}>\mathrm{FeCu}>\mathrm{PdAu}>\mathrm{Au}>\mathrm{Pd}>\mathrm{Fe}>\mathrm{AuFe}$. Furthermore, the bimetallic $\mathrm{AuFe} / \mathrm{TiO}{ }_{2}$ system was found to be the best and most active catalyst for the selective conversion of $\alpha$-pinene to pinene oxide after 24 hours at a temperature of 70 ${ }^{\circ} \mathrm{C}$. The mass of the catalyst and reaction time greatly influenced the oxidation rate of $\alpha$-pinene.
\end{abstract}

Keywords: Bimetallic catalyst; $\alpha$-pinene; Gold catalyst; Green monomers

\section{Introduction}

Softwood such as coniferous trees like pines are important sources of terpenes like $\alpha$-pinene, which can be used to provide renewable raw materials for the manufacturing of other valuable fine products [1-4]. For instance, $\alpha$-Pinene is the main constituent of gum turpentine [5-8], which is considered as a renewable and inexpensive starting material for producing various materials such as medicines, fragrances, agrochemicals, and flavors [9]. $\alpha$-pinene is one of two isomers of pinene, which contains a reactive fourmembered ring. The oxidation of $\alpha$-pinene will be industrially important since it enables transformation of readily available and inexpensive substrates to valuable chemicals through catalytic employed processes.

For polymer scientists, the development of new renewable monomers and polymers from natural resources has increasingly gained attention from scientists. $\alpha$-Pinene is the most abundant of the terpenic compounds which could serve as an ideal green and sustainable monomeric materials. Unfortunately, the polymerization of $\alpha$-pinene proceeds with a relatively low yield [10]. However, in recent years researchers reported the successful polymerization of $\alpha$-pinene oxide via ring opening polymerization. Kheira et al. [11] studied the cationic polymerization of $\alpha$-pinene oxide with heterogeneous clay catalyst. The poly ( $\alpha$-pinene oxide) was prepared from $\alpha$-pinene oxide using Maghnite $\mathrm{H}+$ as a catalyst. The authors showed that the polymerization proceeded smoothly and a simple filtration step was sufficient to recover the catalyst. The successful polymerization of this monomer could open the door to create new and green polymers with a wide range of mechanical properties that positions them ideally for various applications such as plastic packaging, cosmetic and medical applications [12]

Currently, the challenging goal to polymer scientists and chemists is to develop catalytic methods suitable for the selective oxidation of $\alpha$-pinene using green oxidants. Various catalytic materials have been reported including both heterogeneous and homogeneous catalysts [1-4], however the use of green and efficient catalysts is still actively investigated. Catalysts based on gold nanoparticles deposited on several solid supports, particularly on reducible oxides such as $\mathrm{CeO}_{2}, \mathrm{TiO}_{2}, \mathrm{Fe}_{2} \mathrm{O}_{3}, \mathrm{Fe}_{3} \mathrm{O}_{4}$ and $\mathrm{ZrO}_{2}$, have attracted substantial attention as highly eco-friendly, and active catalysts utilized in hydrogenation, oxidation and hydrochlorination reactions [1]. Also, bimetallic catalysts now exist with an advantage of catalytic activities that transcend those of their monometallic analogues [1]. In recent years, bimetallic gold-containing catalysts have drowned a considerable attention particularly for the oxidation of $\alpha$-pinene. For instance, a series of bimetallic catalysts 
$\mathrm{Au}-\mathrm{M}$ (M represents transition metals such as $\mathrm{Co}, \mathrm{Cu}$ and $\mathrm{Ru}$ ) were efficiently supported on $\mathrm{TiO}_{2}$ through deposition-precipitation method and utilised to oxidise $\alpha$-pinene with a remarkable activity. It was found that the alloyed particles were capable of converting $\alpha$-pinene concordant as follows: $\mathrm{AuCu} / \mathrm{TiO}_{2}$ being the most active, followed by $\mathrm{AuCo} / \mathrm{TiO}_{2}$, then $\mathrm{Cu} / \mathrm{TiO}_{2}$, followed by $\mathrm{Au} / \mathrm{TiO}_{2}$, and lastly $\mathrm{AuRu} / \mathrm{TiO}_{2}$ as the least active [13]. By comparison, $\mathrm{Au}-\mathrm{Cu} /$ $\mathrm{TiO}_{2}$ was observed to be the most selective and active catalyst towards the formation of verbenone [13].

In most heterogeneous catalysts, the lack of stability is a challenging goal to organic chemists. For instance, during oxidation of $\alpha$-pinene, agglomeration of particles often blocks the active site of the catalyst, contributing to its instability. As mentioned above, $\mathrm{TiO}_{2}$ has been developed and used as a successful alternative support for heterogeneous catalyst [14-17]. $\mathrm{TiO}_{2}$ has high surface area that stabilises the catalysts, especially in its mesoporous structure. Also, $\mathrm{TiO}_{2}$ as a support on heterogeneous catalysts influence bifunctional mechanism. It enforces an electronic effect, which allows for the promotion of the electrolytic characteristics of hyper-delectronic noble catalyst surface atom by the hypo-d-electronic $\mathrm{Ti} 3+[14]$. In addition, it has high activity for several oxidation and reduction reactions at low temperatures and pressures. Moreover, $\mathrm{TiO}_{2}$ is a superior metal oxide catalyst support owing to its chemical stability, strong metal support interaction, and acid-base properties. These properties provide high potential applications for the heterogeneous $\mathrm{TiO}_{2}$ supported catalysts in the synthesis of fine chemicals and photocatalyst-related applications [14].

Impregnation is the simplest known method used for the preparation of gold-supported catalysts. It comprises of wetting the support using an aqueous solution consisting of the metal precursor, normally $\mathrm{AuCl}_{3}$ or tetrachloroauric acid $\left(\mathrm{HAuCl}_{4}\right)$ [1822]. Subsequently, the sample is dried, and a thermal treatment then conducted to reduce the precursor into metallic particles [18]. The thermal treatment could be conducted under an oxidizing gas such as oxygen or reducing gas such as hydrogen; in both cases, Au is reduced due to the instability of Au (III) compounds. The limitation of impregnation method is that the Au precursor's chlorides are also present on the support, leading to the formation of large gold particles [18]. However, despite the drawback, this method can be employed with wide variety of supports [18].

The present study aims at testing the selective oxidation of $\alpha$-pinene to pinene oxide with different catalysts using $\mathrm{TiO}_{2}$ as a support that has been prepared by an impregnation method. This could open the door for the large-scale production of new renewable materials which can be used as ideal green and sustainable monomers from abundant natural resources.

\section{Experimental}

\section{Materials}

$\mathrm{TiO}_{2}$ was used as a catalyst support and $\mathrm{HAuCl}_{4} \bullet \mathrm{H}_{2} \mathrm{O}$ was used as the gold source. Metals which included $\mathrm{Cu}, \mathrm{Fe}, \mathrm{Pd}$, Co were used as a chloride or nitrate salt. $\alpha$-pinene $(98 \%)$ was used as received.

\section{Catalysts preparation by impregnation method}

The catalysts prepared included $5 \% \mathrm{Au} / \mathrm{TiO}_{2}, 5 \% \mathrm{Cu} / \mathrm{TiO}_{2}$, $5 \% \mathrm{Pd} / \mathrm{TiO}_{2}, 5 \% \mathrm{Fe} / \mathrm{TiO}_{2}, 2.5 \mathrm{wt} \% \mathrm{Co}+2.5 \% \mathrm{wt} \mathrm{Cu} / \mathrm{TiO}_{2}, 2.5 \mathrm{wt} \%$ $\mathrm{Au}+2.5 \mathrm{wt} \% \quad \mathrm{Cu} / \mathrm{TiO}_{2}, \quad 2.5 \mathrm{wt} \% \quad \mathrm{Pd}+2.5 \mathrm{wt} \% \quad \mathrm{Cu} / \mathrm{TiO}_{2}, \quad 2.5 \mathrm{wt} \%$ $\mathrm{Fe}+2.5 \mathrm{wt} \% \mathrm{Cu} / \mathrm{TiO}_{2}, 2.5 \mathrm{wt} \% \mathrm{Pd}+2.5 \mathrm{wt} \% \mathrm{Au} / \mathrm{TiO}_{2}, 2.5 \mathrm{wt} \% \mathrm{Au}+2.5$ $\mathrm{wt} \% \mathrm{Fe} / \mathrm{TiO}_{2}$.

The impregnation method for preparing the supported metal catalysts was conducted in accordance to the description given in references [23-26]. In its essential features, the impregnation method required that the support be contacted with a specific quantity of solution of the metal precursor, normally a salt, and then aged, dried and calcined. Wet" or "soaking" impregnation involved the utilization of the excess amount of the solution with respect to the support's pore volume. The system was left to age for a specific amount of time under stirring, then filtered and dried.

In a typical experiment, $0.067 \mathrm{~g}$ of copper (II) chloride was weighed into a beaker. Then, $2.5 \mathrm{ml}$ of $\mathrm{HAuCl}_{4}$ added to the beaker that contained copper (II) chloride. The solution was then stirred until the copper salt dissolved into the Au solution. After which $0.95 \mathrm{~g}$ of $\mathrm{TiO}_{2}$ was added to the AuCu solution and stirred until an even mixture was formed. The drying process was then conducted as follows: $10 \mathrm{mg}$ of an aqueous solution of $\mathrm{HAuCl}_{4} \bullet 3 \mathrm{H}_{2} \mathrm{O}$ was added to $0.95 \mathrm{~g}$ of the support under stirring. The paste formed was then dried at $110{ }^{\circ} \mathrm{C}$ for 16 hours and calcined in static air, typically at $400{ }^{\circ} \mathrm{C}$ for 3 hours, to reduce the precursor into metallic particles.

\section{Reaction setup}

The oxidation of $\alpha$-pinene was conducted in accordance with the description provided in references [1,3]. In a typical experiment, the oxidation of $\alpha$-pinene was carried out in a multiple reactors with a magnetic stirrer (1000r.p.m.), maintained at $70{ }^{\circ} \mathrm{C}$ and $\mathrm{P}\left(\mathrm{O}_{2}\right)=2$ bar. During the reaction, $2 \mathrm{~g}(2.33 \mathrm{ml})$ of $\alpha$-pinene $(98 \%)$, and $20 \mathrm{mg}$ of catalyst was constantly stirred in order to obtain the homogenous combination of catalyst with the reaction mixture. Next, the reaction progress was monitored by taking samples at different time intervals ( 4 and $24 \mathrm{~h}$ ). Analysis of the products was carried out using Gas Chromatography-Flame Ionization Detector (GC/FID).

\section{Results and Discussion}

\section{Conversion of $\alpha$-Pinene to its oxidized products}

Oxidation of $\alpha$-pinene proceeded smoothly at $70{ }^{\circ} \mathrm{C}$ over all the $\mathrm{Au}-\mathrm{M} / \mathrm{TiO}_{2}$ catalysts prepared by the impregnation method. According to GC/FID results, the observed oxidation products were mainly pinene oxide, verbenol, verbenone, carveol, and carvone. This is in line with the observations from various studies in the literature [27-29]. For instance, Erman [27] reported that catalytic oxidation of $\alpha$-pinene can yield $\alpha$-pinene oxide. Silva et al. [28] finding also supports the observation of the present study. Others also reported that cobalt catalyzed $\alpha$-pinene oxidation can yield $\alpha$-pinene oxide, carveol, verbenone, and verbenol. Similarly, Prunier [29] back up the observation of the present study by stating that carvone is one of the products resulting from oxidation of $\alpha$-pinene. 
In our study, the response factors obtained were utilized when calculating selectivity and conversion of $\alpha$-pinene as well as its oxidation products as presented in Table 1 and Figure 1. From Table 1 and Figure 1, the conversion of $\alpha$-pinene to its oxidized products under $5 \% \mathrm{Fe} / \mathrm{TiO}_{2}$ catalyst prepared by impregnation method was only $5.8 \%$ at a temperature of $70{ }^{\circ} \mathrm{C}$ and a time $=4 \mathrm{~h}$. This conversion was highly selective to the formation of carvone $(8.7 \%)$, then verbenol (7.1\%), followed by verbenone (6.7\%), and lastly carveol $(2.9 \%)$.

Table 1: Oxidation of a-pinene with $20 \mathrm{mg}$ of $5 \% \mathrm{Fe} / \mathrm{TiO} 2$ at time $=4 \mathrm{~h}$; temperature $=70{ }^{\circ} \mathrm{C} ; \mathrm{P}(\mathrm{O} 2)=2 \mathrm{bar}$ and $1000 \mathrm{r} \cdot \mathrm{p} \cdot \mathrm{m}$. stirrer speed.

\begin{tabular}{|c|c|c|c|c|c|}
\hline & Area & Response Factor & Moles & Conversion \% & Selectivity \% \\
\hline Pinene & $6.39 \mathrm{E}+08$ & $1.20 \mathrm{E}+11$ & 0.0052597 & 5.8 & \\
\hline Pinene Oxide & 17259542 & $1.10 \mathrm{E}+11$ & $1.50 \mathrm{E}-04$ & & 47.2 \\
\hline Vebenol & 2475239 & $1.10 \mathrm{E}+11$ & $2.33 \mathrm{E}-05$ & & 7.1 \\
\hline Carveol & 2459243 & $1.10 \mathrm{E}+11$ & $2.19 \mathrm{E}-05$ & & 6.7 \\
\hline Vebenon & 1028992 & $1.10 \mathrm{E}+11$ & $9.30 \mathrm{E}-06$ & & 2.9 \\
\hline Carvone & 3178787 & $1.10 \mathrm{E}+11$ & 2.83E-05 & & 8.7 \\
\hline Unknown & 9877083 & $1.10 \mathrm{E}+11$ & $8.93 \mathrm{E}-05$ & & 27.4 \\
\hline Total Product & & & $3.30 \mathrm{E}-04$ & & \\
\hline Total & & & 0.0055856 & & \\
\hline
\end{tabular}

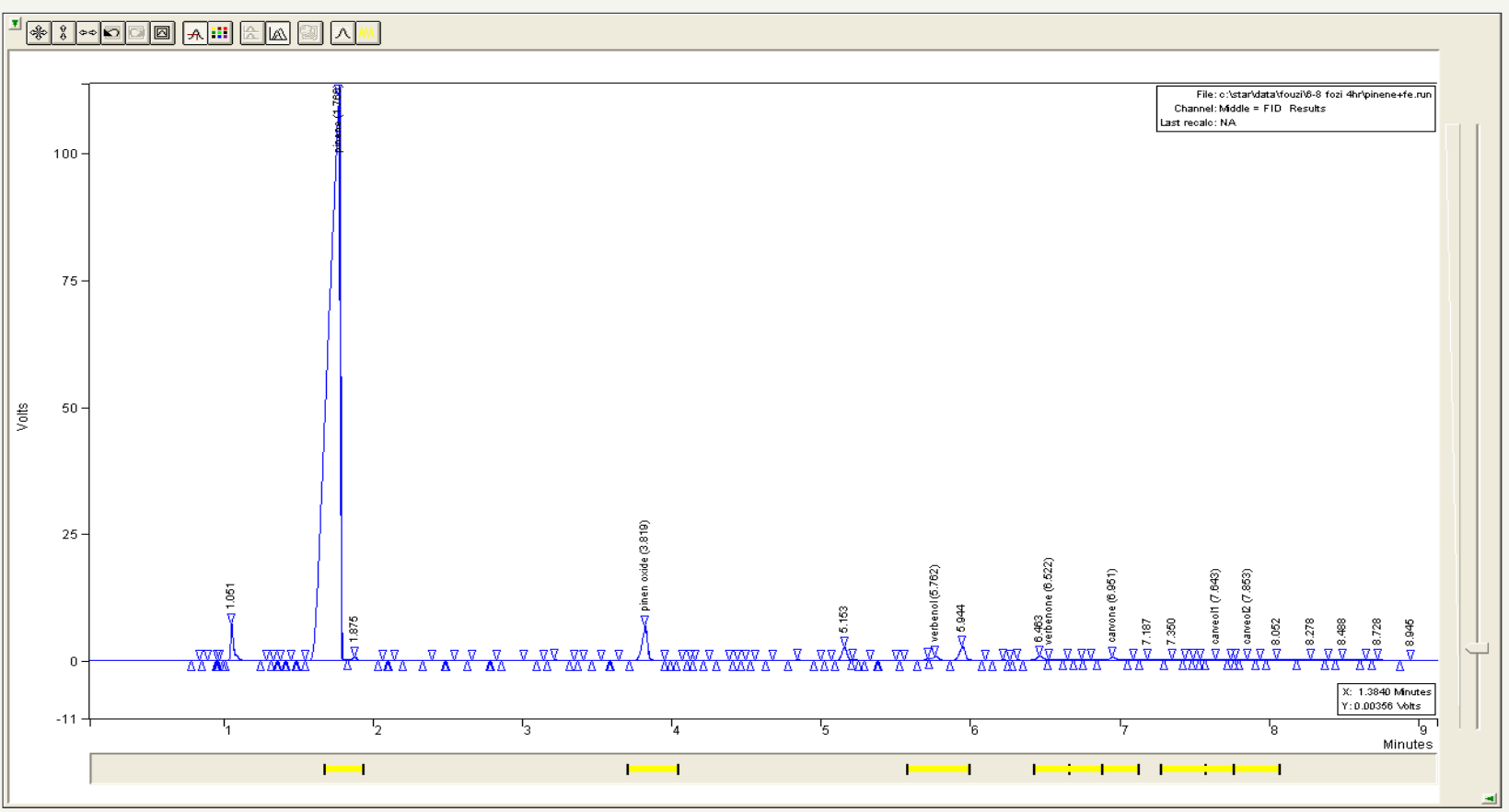

Figure 1: Oxidation of a-pinene with $20 \mathrm{mg}$ of $5 \% \mathrm{Fe} / \mathrm{TiO}_{2}$ at time $=4 \mathrm{~h}$; temperature $=70 \mathrm{oC} ; \mathrm{P}\left(\mathrm{O}_{2}\right)=2 \mathrm{bar}$; and $1000 \mathrm{rpm}$ stirrer speed. 


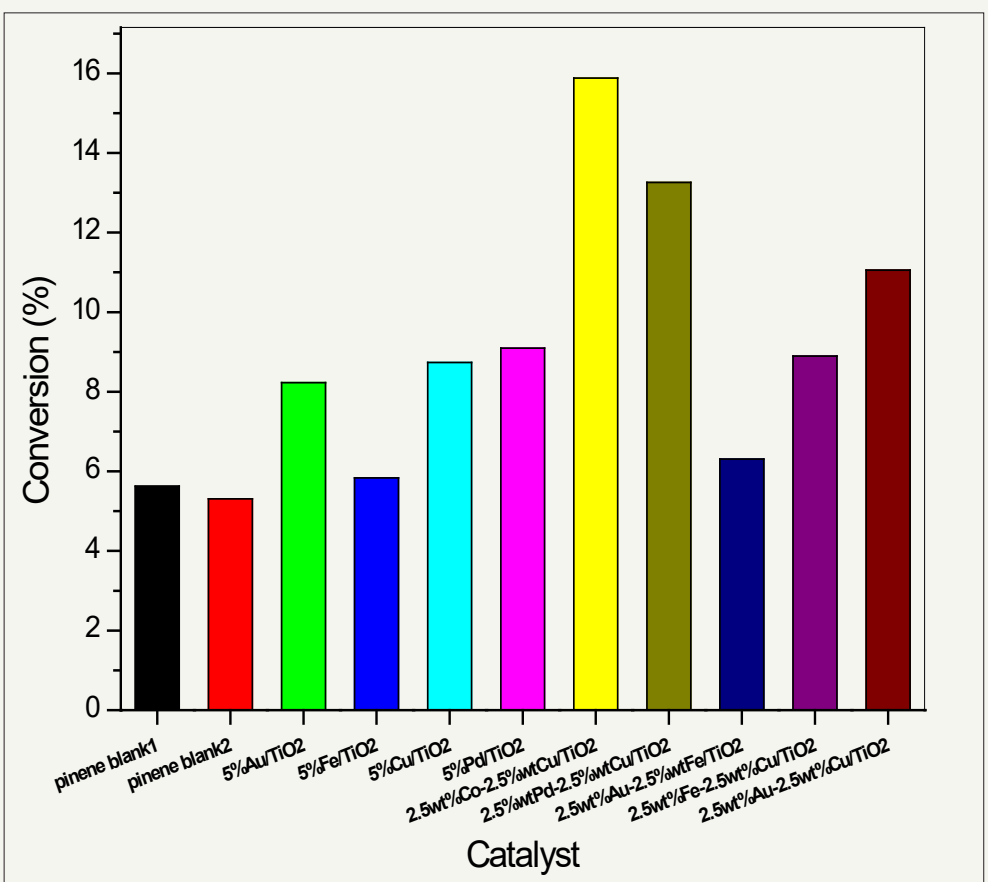

Figure 2: Conversion of a-pinene by $20 \mathrm{mg}$ of different catalysts at time $=4 \mathrm{~h}$; temperature $=70{ }^{\circ} \mathrm{C} ; \mathrm{P}\left(\mathrm{O}_{2}\right)=2$ bar and stirrer speed of 1000r.p.m.

Figure 2 indicates that the order of conversion of $\alpha$-pinene to its oxidized products was $\mathrm{CoCu}>\mathrm{PdCu}>$ $\mathrm{AuCu}>\mathrm{Pd}>\mathrm{FeCu}>\mathrm{Cu}>\mathrm{Au}>\mathrm{AuFe}>\mathrm{Fe} . \mathrm{CoCu} / \mathrm{TiO}_{2}$ catalyst showed the highest conversion because its particles were finely distributed on the support. Just as found by Ajaikumar et al. [1], of all the prepared catalysts they tested, $\mathrm{AuCu} / \mathrm{TiO}_{2}$ showed the highest catalytic activity in the conversion of $\alpha$-pinene followed by AuCo/ $\mathrm{TiO}_{2}$. Therefore, it is that $\mathrm{CoCu} / \mathrm{TiO}_{2}$ show the highest conversion as reflected on the results shown in Figure 2.

\section{Selectivity study of the oxidation of $\alpha$-Pinene}

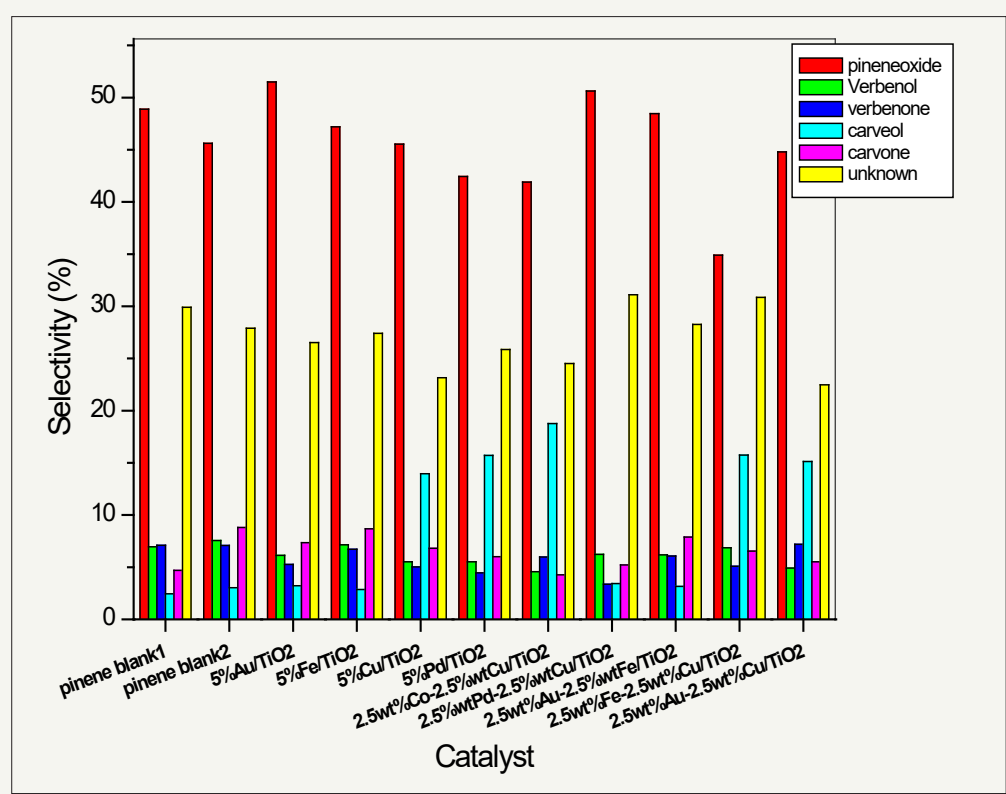

Figure 3: Products selectivity by $20 \mathrm{mg}$ of different catalysts at time $=4 \mathrm{~h}$; temperature $=70{ }^{\circ} \mathrm{C} ; \mathrm{P}\left(\mathrm{O}_{2}\right)=2$ bar and stirrer speed of 1000r.p.m.

From Figure 3, one can see that the monometallic $\mathrm{Au} / \mathrm{TiO}_{2}$ supported catalyst prepared by impregnation method was highly selective in the formation of pinene oxide (51.50\%) at a temperature of $70{ }^{\circ} \mathrm{C}$ and time $=4 \mathrm{~h}$. However, $\mathrm{Fe} / \mathrm{TiO}_{2}$ catalyst prepared by impregnation method was highly selective in the formation of verbenol (7.14\%) and carvone (8.68\%) and a temperature of $70{ }^{\circ} \mathrm{C}$ 
and time $=4 \mathrm{~h}$. Under the same conditions, the bimetallic $\mathrm{AuCu} / \mathrm{TiO}_{2}$ catalyst prepared by impregnation method was highly selective in the formation of verbenone (7.18\%). Also, $\mathrm{CoCu} / \mathrm{TiO}_{2}$ prepared by the same method used to prepare the previously mentioned catalyst was highly selective in the formation of carveol (18.76\%) at $70{ }^{\circ} \mathrm{C}$ and time $=4 \mathrm{~h}$.

Ajaikumar et al. [1] also found that the bimetallic $\mathrm{AuCu}$ titania supported catalyst prepared by deposition precipitation method is highly selective towards the formation of verbenone. On the contrary, they observed that $\mathrm{AuRu} / \mathrm{TiO}_{2}$ prepared with the same method they used to prepare $\mathrm{AuCu} / \mathrm{TiO}$, was highly selective towards the formation of verbenol (22.1\%) at $70{ }^{\circ} \mathrm{C}$ [1]. It is clear that their result achieved a higher percentage of verbenol selectivity as compared to that of the present study. Perhaps this was so because of the differences in reaction time and conditions.

In our study, an interesting feature also occurred after 4 hours when $\mathrm{Au} / \mathrm{TiO}_{2}$ prepared by impregnation method was observed to be the most suitable catalyst in the conversion of $\alpha$-pinene to the compound of interest, pinene oxide. On the contrary, Ajaikumar et al. [1] noticed that the monometallic $\mathrm{Au}$ titania supported catalyst prepared by deposition precipitation method yields lower conversion than its bimetallic systems, and that it shows high activity towards the production of t-butyl pinene peroxide. The catalytic activity of $\mathrm{Fe} / \mathrm{TiO}_{2}$ also requires further study, as the catalyst showed high activity in the selective formation of verbenol and carvone within 4 hours.

Figure 4 shows that the bimetallic $2.5 \mathrm{wt} \% \mathrm{Fe}+2.5 \mathrm{wt} \% \mathrm{Au} /$ $\mathrm{TiO}_{2}$ catalyst prepared by impregnation method achieved the best selectivity of pinene oxide (51.69\%), and so this catalyst proves to be the best among all the tested catalysts in the selective oxidation of $\alpha$-pinene to form pinene oxide. Unfortunately, the oxidation of $\alpha$-pinene to form pinene oxide over gold supported catalysts has been limitedly studied. Much of the attentions have only been focused on the conversion of $\alpha$-pinene to common products like verbenone. Nonetheless, Karlsson [30] studied the oxidation of $\alpha$-pinene to form pinene oxide under different catalysts for 22 hours. In Karlsson [30] study, $\mathrm{Nb} / \mathrm{SiO}_{2}$ showed the highest catalytic activity of only $10.1 \%$ in the selective conversion of $\alpha$-pinene to pinene oxide. Therefore, the yield from the present study indicates that $\mathrm{FeAu} / \mathrm{TiO}_{2}$ catalysis is the best in the selective conversion of $\alpha$-pinene to pinene oxide.

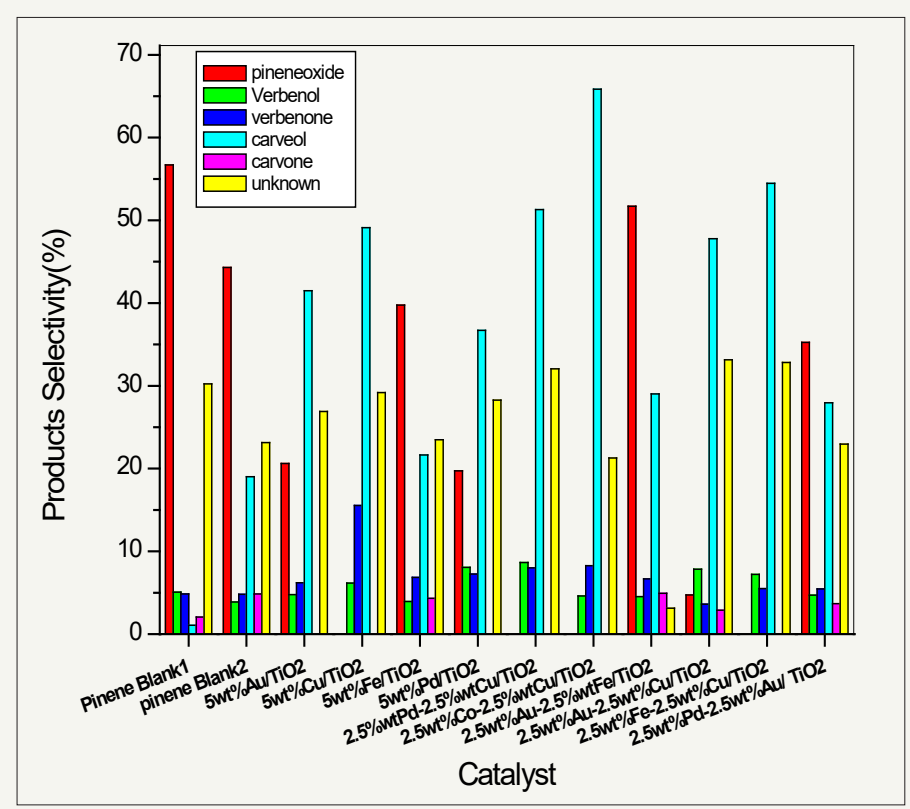

Figure 4: Products selectivity by $20 \mathrm{mg}$ of different catalysts at time $=24 \mathrm{~h}$; temperature $=70{ }^{\circ} \mathrm{C} ; \mathrm{P}\left(\mathrm{O}_{2}\right)=2$ bar and stirrer speed of 1000r.p.m.

Figure 5 confirms that the bimetallic, $2.5 \mathrm{wt} \% \mathrm{Fe}+2.5 \mathrm{wt} \%$ $\mathrm{Au} / \mathrm{TiO}_{2}$ prepared by impregnation method, is the most selective catalyist for the oxidation of $\alpha$-pinene to form pinene oxide. The achieved highest selectivity for this desired product was $51.69 \%$. Davis \& Occelli [31] have previously studied the application of iron as a catalyst and found why this transition metal is significant in this type of oxidation reactions. For instance, it is applicable not only in the Fischer-Tropsch synthesis but also during the conversion of low $\mathrm{H}_{2} / \mathrm{CO}$ ratio synthesis gas. Davis \& Occelli [31] observed that iron-based catalyst yields hydrocarbons that have higher $\alpha$-values. Indeed, this is the reason why iron-based catalysts resulted into the highest percentage yield of $\alpha$-pinene oxide. Avgouropoulos \& Tabakova [32] also studied the effect of addition of iron in the gold catalyst during the oxidation of carbon monoxide and found that iron enhances the catalytic activity of gold especially at low temperatures. The AuFe catalyst studied by Avgouropoulos \& Tabakova [32] was also found to be very active and selective.

Figure 5 also confirms that $2.5 \mathrm{wt} \% \mathrm{Co}+2.5 \mathrm{wt} \% \mathrm{Cu} / \mathrm{TiO}_{2}$ catalyst prepared by impregnation method gives the highest conversion of $\alpha$-pinene $(62.47 \%)$ after 24 hours at $70{ }^{\circ} \mathrm{C}$. Based on this observation, the nature of metallic as well as bimetallic particles greatly influences the rate of reaction. Indeed, the $\mathrm{CoCu}$ / 
$\mathrm{TiO}_{2}$ exhibited the highest conversion because the particles of the bimetallic supported catalyst were finely distributed on the support. In addition, as mentioned before, the particle size distribution in $\mathrm{CoCu} / \mathrm{TiO}_{2}$ was narrow with small particle diameter. Ajaikumar et al. [1] also noticed this observation in their experiment to investigate the oxidation of $\alpha$-pinene over gold catalysts prepared by deposition precipitation method. In their study, they discovered that of all the metallic and bimetallic supported catalyst prepared by deposition precipitation method tested, $\mathrm{AuCu} / \mathrm{TiO}_{2}$ followed by $\mathrm{AuCo} / \mathrm{TiO}_{2}$, exhibited the highest catalytic activity in the conversion of $\alpha$-pinene to its oxidation products. In addition, through transmission electron microscopy, they noticed that $\mathrm{AuCu}$ / $\mathrm{TiO}_{2}$ and $\mathrm{AuCo} / \mathrm{TiO}_{2}$ exhibited narrow particle size distribution and the smallest mean diameters of approximately $3.8 \mathrm{~nm}$ and $3.6 \mathrm{~nm}$ respectively [1]. In the present study, the catalytic activity of $2.5 \mathrm{wt} \% \mathrm{Co}+2.5 \mathrm{wt} \% \mathrm{Cu} / \mathrm{TiO}_{2}$ was studied and found to yield the highest conversion of $\alpha$-pinene to its oxidation products. Since both $\mathrm{AuCu} / \mathrm{TiO}_{2}$ and $\mathrm{AuCo} / \mathrm{TiO}_{2}$ are active in the conversion of $\alpha$-pinene, the catalytic activity of $2.5 \mathrm{wt} \% \mathrm{Co}+2.5 \mathrm{wt} \% \mathrm{Cu} / \mathrm{TiO}_{2}$ should also be very active, as reflected in the results.

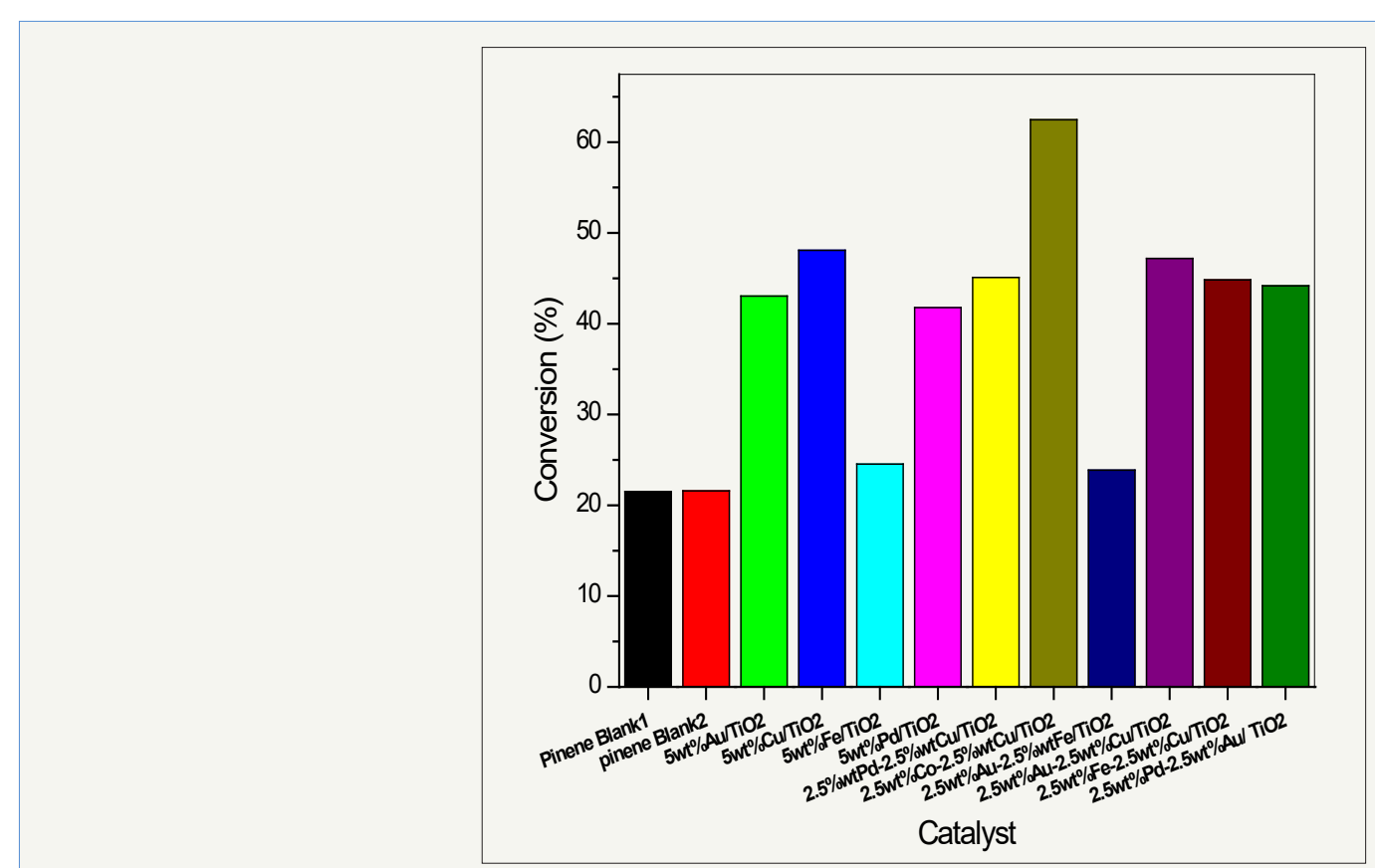

Figure 5: The conversion a-pinene by $20 \mathrm{mg}$ of different catalysts at time $=24 \mathrm{~h}$; Temperature $=70{ }^{\circ} \mathrm{C}, \mathrm{P}\left(\mathrm{O}_{2}\right)=2$ bar; and stirrer speed of 1000r.p.m.

\section{Effect of catalyst mass on the oxidation of $\alpha$-Pinene}

From the results presented in Table 2 , it is clear that any increase in the mass of catalyst increases the conversion of $\alpha$-pinene, but decreases the selectivity of pinene oxide. Balázs et al. [33] previously studied the effect of increasing mass (concentration) of the catalyst on $\alpha$-pinene conversion. Although their study was slightly different from that of the present study, there is a close link between the two researches. Balázs et al. [33] studied the effect of catalyst concentration on the selective conversion of $\alpha$-pinene to camphene. Their reaction was conducted at $130{ }^{\circ} \mathrm{C}$, utilizing different $\alpha$-pinene/catalyst ratios, as follows: $100 / 0.25,100 / 0.5$ and $100 / 1$. They observed that the selectivity of camphene reduced when the ratio $\alpha$-pinene/catalyst was increased, implying that selectivity decreased with an increase in concentration (loading) of the catalyst. Perhaps this is attributed to the weak stability of the camphene, which may eventually lead to the formation of other $\alpha$-pinene derivatives. Similarly, the concept of Balázs et al. [33] can be used to explain why selectivity of pinene oxide decreased when the mass of the catalyst was increased. Increasing the mass of the catalyst lowers the stability of pinene oxide formed, causing it to form other $\alpha$-pinene derivatives.

Table 2: Conversion of 2 grams of a-pinene over $10 \mathrm{mg}, 20 \mathrm{mg}$ and $50 \mathrm{mg}$ of $2.5 \mathrm{wt} \% \mathrm{Pd}+2.5 \mathrm{wt} \% \mathrm{Au} / \mathrm{TiO} 2$ at time=24h; temperature $=70^{\circ} \mathrm{C} ; \mathrm{P}(\mathrm{O} 2)=2 \mathrm{bar}$, and stirrer speed of $1000 \mathrm{r} . \mathrm{p} . \mathrm{m}$.

\begin{tabular}{|c|c|c|c|c|c|c|c|c|c|}
\hline \multicolumn{10}{|c|}{ Selectivity \% } \\
\hline Catalyst & Mass/mg & $\underset{\text { Time }}{\text { Time }}$ & $\begin{array}{c}\text { Conversion } \\
\%\end{array}$ & $\begin{array}{c}\text { Pinene } \\
\text { oxide }\end{array}$ & Verbenol & Verbenon & Carveol & Carvone & Unknown \\
\hline $2.5 w t \% \mathrm{Pd}-2.5 \mathrm{wt} \% \mathrm{Au} / \mathrm{TiO}_{2}$ & 10 & 24 & 35.89 & 49.43 & 5.76 & 5.69 & 3.51 & 4.86 & 30.76 \\
\hline $2.5 w t \% \mathrm{Pd}-2.5 \mathrm{wt} \% \mathrm{Au} / \mathrm{TiO}_{2}$ & 20 & 24 & 44.17 & 35.25 & 4.7 & 5.46 & 27.96 & 3.67 & 22.96 \\
\hline $2.5 w t \% \mathrm{Pd}-2.5 w t \% \mathrm{Au} / \mathrm{TiO}_{2}$ & 50 & 24 & 48.91 & 26.56 & 6.11 & 5.64 & 37.11 & 0 & 24.57 \\
\hline
\end{tabular}


Balázs et al. [33] observed an interesting (but same with the observation from the present study) phenomenon when the mass of the catalyst was increased during conversion of $\alpha$-pinene to form camphene. These scholars observed that four days were required for a desired conversion of $\alpha$-pinene when less catalyst (in the ratio of 100/0.25) was utilized, but only a few minutes was enough when

\section{Effect of reaction time on the oxidation of $\alpha$-Pinene}

Table 3: Oxidation of a-pinene over $2.5 \mathrm{wt} \% \mathrm{Fe}+2.5 \mathrm{wt} \% \mathrm{Au} / \mathrm{TiO}_{2}$ at varied time; temperature $=70{ }^{\circ} \mathrm{C} ; \mathrm{P}\left(\mathrm{O}_{2}\right)=2 \mathrm{bar} ;$ and stirrer speed of 1000r.p.m.

\begin{tabular}{|c|c|c|c|c|c|c|c|c|c|}
\hline \multicolumn{10}{|c|}{ Selectivity \% } \\
\hline Catalyst & Mass/mg & Time $/ \mathbf{h}$ & $\begin{array}{c}\text { Conversion } \\
\%\end{array}$ & $\begin{array}{c}\text { Pinene } \\
\text { oxide }\end{array}$ & Verbenol & Verbenon & Carveol & Carvone & Unknown \\
\hline 2.5wt $\% \mathrm{Au}-2.5-\mathrm{wt} \% \mathrm{Fe} / \mathrm{TiO}_{2}$ & 20 & 0.5 & 4.63 & 45.88 & 10.32 & 5.82 & 2.81 & 8.77 & 26.39 \\
\hline 2.5wt $\% \mathrm{Au}-2.5-\mathrm{wt} \% \mathrm{Fe} / \mathrm{TiO}_{2}$ & 20 & 1 & 5.2 & 44.3 & 7.71 & 7.69 & 5.92 & 8.36 & 25.99 \\
\hline 2.5wt $\% \mathrm{Au}-2.5-\mathrm{wt} \% \mathrm{Fe} / \mathrm{TiO}_{2}$ & 20 & 2 & 5.73 & 45.75 & 6.91 & 5.54 & 7.2 & 8.18 & 26.39 \\
\hline 2.5wt $\% \mathrm{Au}-2.5-\mathrm{wt} \% \mathrm{Fe} / \mathrm{TiO}_{2}$ & 20 & 4 & 6.3 & 48.46 & 6.17 & 6.06 & 3.15 & 7.87 & 28.25 \\
\hline 2.5wt $\% \mathrm{Au}-2.5-\mathrm{wt} \% \mathrm{Fe} / \mathrm{TiO}_{2}$ & 20 & 6 & 10.41 & 43.72 & 4.39 & 5.63 & 15.65 & 6.29 & 24.29 \\
\hline 2.5wt $\% \mathrm{Au}-2.5-\mathrm{wt} \% \mathrm{Fe} / \mathrm{TiO}_{2}$ & 20 & 24 & 23.87 & 51.69 & 4.53 & 6.67 & 29.02 & 4.93 & 3.13 \\
\hline
\end{tabular}

The results presented in Table 3 indicate that the conversion of $\alpha$-pinene increases as time increases. Ajaikumar et al. [1], Yan Chun [35], Rachwalik et al. [36] also studied the influence of time of reaction on the selective conversion of $\alpha$-pinene. Interestingly, both of them noticed that the conversion of $\alpha$-pinene increases with any increase in the reaction time. Ajaikumar et al. [1] studied the effect of reaction time on oxidation of $\alpha$-pinene by carrying out the reaction at various reaction times and varying the temperature from room temperature to $90^{\circ} \mathrm{C}$. They observed that the oxidation of $\alpha$-pinene selectively increased when the reaction time was increased up to a temperature of $70^{\circ} \mathrm{C}$ [1]. However, these scholars also noticed that there was no significant change in the distribution of products as time increased at room temperature [1]

\section{Conclusion}

The catalytic oxidation of $\alpha$-pinene over various monometallic and bimetallic gold-containing catalysts prepared by impregnation method was studied at a temperature of $70{ }^{\circ} \mathrm{C}$. The major products formed were pinene oxide, verbenol, verbenone, carveol, and carvone. The monometallic $\mathrm{Au} / \mathrm{TiO}_{2}$ catalyst prepared by impregnation method proved to be the best catalyst for the selective conversion of $\alpha$-pinene to form the desired product of pinene oxide, after only 4 hours. However, after 24 hours of the reaction time, the bimetallic $2.5 \mathrm{wt} \% \mathrm{Fe}+2.5 \mathrm{wt} \% \mathrm{Au} / \mathrm{TiO}_{2}$ catalyst prepared by impregnation method achieved the best selectivity for the formation of pinene oxide with the greatest percentage yield during the entire reaction, making it the best catalyst for oxidation of $\alpha$-pinene to form pinene oxide.

Other catalysts apart from the $\mathrm{AuFe} / \mathrm{TiO}_{2}$ system also showed efficient results during the oxidation of $\alpha$-pinene. For instance, $\mathrm{CoCu}$ titania supported catalyst prepared by impregnation method showed the highest conversion of $\alpha$-pinene with a beneficial percentage yield after 24 hours. The same catalyst was found to be highly selective in the formation of carveol. Generally, the order of conversion was more catalyst was added (in the ratio of 100/1). Their observation is in line with that from the present study since the conversion of $\alpha$-pinene increased with an increase in the catalytic mass. Indeed, this is because of the fact that any increase in the mass of the catalyst increases the surface area of the catalyst [34].

observed as $\mathrm{CoCu}>\mathrm{Cu}>\mathrm{AuCu}>\mathrm{PdCu}>\mathrm{FeCu}>\mathrm{PdAu}>\mathrm{Au}>\mathrm{Pd}>\mathrm{Fe}>\mathrm{AuFe}$ after 24 hours.

Similarly, $2.5 \% \mathrm{wtPd}+2.5 \% \mathrm{wtCu} / \mathrm{TiO}_{2}$ catalyst prepared by impregnation method was found to be highly selective in the formation of verbenol after 24 hours. On the other hand, $5 w t \% \mathrm{Cu}$ / $\mathrm{TiO}_{2}$ prepared by impregnation method was observed to be the best catalyst in the selective oxidation of $\alpha$-pinene for 24 hours to yield verbenone.

The effect of increase in mass of the catalyst and reaction time on the conversion of $\alpha$-pinene was also studied. It was observed that the catalytic conversion of $\alpha$-pinene increased when the reaction time was increased. Selectivity was also observed to increase when the reaction time was increased. Nonetheless, although an increase in mass of the catalyst led to an increase in conversion of $\alpha$-pinene, selectivity was greatly reduced.

This study provided useful insight in the application of goldbimetallic catalysts in the selective oxidation of $\alpha$-pinene, especially in the production of pinene oxide as the desired product. From the present study's observations, it can be deduced that the bimetallic $\mathrm{AuFe} / \mathrm{TiO}_{2}$ catalyst prepared by impregnation method is active and selective towards the formation of pinene oxide over the oxidation of $\alpha$-pinene at a temperature of $70{ }^{\circ} \mathrm{C}$ for 24 hours. Considering this observation, it would be economical to produce pinene oxide from a green oxidation reaction of $\alpha$-pinene over $\mathrm{AuFe} / \mathrm{TiO}_{2}$ as a catalyst other than $\mathrm{Au} / \mathrm{TiO}_{2}$ or $\mathrm{Fe} / \mathrm{TiO}_{2}$ catalysts alone.

\section{References}

1. Ajaikumar S, Ahlkvist J, Larsson W, Shchukarev A, Leino AR, et al. (2011) Oxidation of $\alpha$-Pinene over gold containing bimetallic nanoparticles supported on reducible $\mathrm{TiO}_{2}$ by deposition-precipitation method. Applied Catalysis A: General 392(1-2): 11-18.

2. Yu S, Solkina, Reshetnikov SI, Estrada M, Simakov A, et al. (2011) Evaluation of gold on alumina catalyst deactivation dynamics during $\alpha$-Pinene isomerisation. Chemical Engineering Journal 176-177: 42-48. 
3. Čejka J, Corma A, Zones S (2010) Zeolites and catalysis: Synthesis, reactions and applications. Wiley-VCH, Weinheim, Germany, p.792.

4. Yang J, Nie Q, Ren M, Feng H, Jiang X, et al. (2013) Metabolic engineering of Escherichia coli for the biosynthesis of alpha-pinene, Biotechnol Biofuels 6(1): 60 .

5. Casuscelli SG, Eimer AG, Canepa A, Heredia CA, Poncio EC, et al. (2008) Ti-MCM-41 as catalyst for $\alpha$-Pinene oxidation study of the effect of Ti content and $\mathrm{H}_{2} \mathrm{O}_{2}$ addition on activity and selectivity. Catalysis Today 133-135: 678-683.

6. Simakova IL, Solkina YS, Moroz BL, Simakova OA, Reshetnikov SI, et al (2010) Selective vapour-phase $\alpha$-Pinene isomerization to camphene over gold-on-alumina catalyst. Applied Catalysis A: General 385(1-2) 136-143.

7. Benedek I, Feldstein M (2009) Technology of pressure-sensitive adhesives and products. CRC Press, Boca Raton, FL, USA, p. 224.

8. Panda H (2008) Handbook on oleoresin and pine chemicals, Asia Pacific Business Press, Delhi, India.

9. Maksimchuk NV, Melgunov MS, Bialon JM, Jarzebski AB, Kholdeeva OA (2005) $\mathrm{H}_{2} \mathrm{O}_{2}$-based allylic oxidation of $\alpha$-Pinene over different single site catalysts. Journal of Catalysis 235(1): 175-183.

10. Armando JD, Silvestre, Gandini A (2009) Terpenes: major sources, properties and applications, in Chapter 2: Monomers, Polymers and Composites from Renewable Resources. Belgacem MN, Gandini A (Eds.), ( $1^{\text {st }}$ edn), Elesvier, Amsterdam, Netherlands, pp. 17-38.

11. Kheira B, Aicha H, Ahmed Y (2015) Polymerization of alpha pinene oxide catalyzed by maghnite $\mathrm{H}+$. Journal of Chemical and Pharmaceutical Research 7(10): 988-993.

12. Sainza MF, Soutoa J, Regentovaa D, Johanssonc MKG, Timhagenc ST et al. (2016) A facile and green route to terpene derived acrylate and methacrylate monomers and simple free radical polymerisation to yield new renewable polymers and coatings. Polymer Chemistry 7: 2882 2888.

13. Pina CD, Falletta E, Rossi M (2012) Update on selective oxidation using gold. Chem Soc Rev 41(1): 350-369.

14. Bagheri S, Julkapli NY, Hamid SBA (2014) Titanium dioxide as a catalyst support in heterogeneous catalysis. Nanotechnology \& Catalysis Research Centre (NANOCAT), IPS Building, University Malaya, Kuala Lumpur, Malaysia, pp. 1-42.

15. Che M, Védrine J (2012) Characterization of solid materials and heterogeneous catalysts, Wiley-VCH, Weinheim, Germany, p. 491.

16. Gai P, Boyes E (2003) Electron microscopy in heterogeneous catalysis. Institute of Physics Pub, Bristol, England, p. 202.

17. Spivey J, Gupta M (2012) Catalysis. RSC Publishing, Cambridge, UK, p. 281.

18. Louis C, Pluchery O (2012) Gold nanoparticles for physics, chemistry and biology. Imperial College Press, London, England, p. 141.
19. Delannoy L, Hassan NE, Musi A, To NL, Krafft J, et al. (2006) Preparation of supported gold nanoparticles by a modified incipient wetness impregnation method. The Journal of Physical Chemistry B 110(45): 22471-22478

20. Luque R, Varma R (2012) Sustainable preparation of metal nanoparticles: methods and applications. Royal Society of Chemistry, Cambridge, UK, p. 37.

21. Corain B, Schmid G, Toshima N (2011) Metal nanoclusters in catalysis and materials science: the issue of size control. Elsevier, Amsterdam, Netherlands, p. 386 .

22. Hashmi A, Toste F (2012) Modern gold catalyzed synthesis, Wiley-VCH, Weinheim, Germany, p. 8.

23. Pinna F (1998) Supported metal catalysts preparation. Catalysis Today 41(1-3): 129-137

24. Campanati M, Fornasari G, Vaccari A (2003) Fundamentals in the preparation of heterogeneous catalysts. Catalysis Today 77(4): 299-314.

25. Wachs I (2009) Catalyst preparation: science and engineering. In: Regalbuto JR (Ed.), Wiley Online Library, Germany.

26. Perego C, Villa P (1997) Catalyst preparation methods. Catalysis Today 34(3-4): 281-305

27. Mark BE (2000) The alpha-pinene route to aroma chemicals, millennium specialty chemicals, Jacksonville, Florida, USA, pp. 75-88.

28. Silva MD, Dutenhefner PR, Menini L, Gusevskaya E (2003) Cobalt catalyzed autoxidation of monoterpenes in acetic acid and acetonitrile solutions. Journal of Molecular Catalysis A: Chemical 201(1-2): 71-77.

29. Prunier LM (2011) Catalysis of organic reactions: twenty-second conference. Taylor \& Francis, CRC Press, Boca Raton, USA.

30. Karlsson A (2013) Oxidation of $\alpha$-Pinene. Industrial Engineering and Chemistry 48(10): 5-34.

31. Davis B, Occelli M (2009) Advances in fischer-tropsch synthesis, catalysts, and catalysis. CRC Press, Boca Raton, USA, p. 120

32. Avgouropoulos G, Tabakova T (2013) Environmental catalysis over goldbased materials. Royal Society of Chemistry, Cambridge, UK, p. 113.

33. Balázs JS, Coroș M, Woiczechowski A, Blãnițã G, Vlassa M (2012) Supported $\mathrm{H}_{4} \mathrm{SiW}_{12} \mathrm{O}_{40}$ catalysts for $\alpha$-pinene isomerization. Central European Journal of Chemistry 10(4): 1208-1217.

34. Prasada TR, Dhar G (1998) Recent advances in basic and applied aspects of industrial catalysis. Elsevier, Amsterdam, Netherlands, p. 261.

35. Chun HY, Xia CC, Chen C (2014) Sodium alginate intercalated zinccontaining layered double hydroxides for the catalytic $\alpha$-pinene oxidation. IBIMA publishing, pp. 1-9.

36. Rachwalik R, Olejniczak Z, Jiao J, Huang J, Hunger M, et al. (2007) Isomerization of $\alpha$-pinene over dealuminated ferrierite-type zeolites. Journal of Catalysis 252(2): 161-170.
Creative Commons Attribution 4.0 International License

For possible submissions Click Here

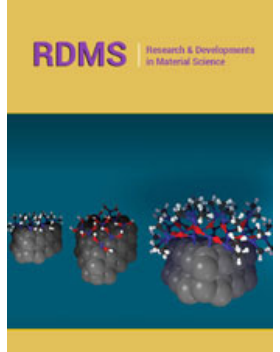

Research \& Development in Material Science

\section{Benefits of Publishing with us}

- High-level peer review and editorial services

- Freely accessible online immediately upon publication

- Authors retain the copyright to their work

- Licensing it under a Creative Commons license

- Visibility through different online platforms 